\title{
MENINGKATKAN POTENSI SUMBER DAYA ALAM UNTUK MEWUJUDKAN DESA WISATA
}

\author{
Retno Wulan Sekarsari' ${ }^{1}$, Juvinta Diva Fabiola², Rahmat Hidayatullah ${ }^{3}$, Dina \\ Oktaviana ${ }^{3}$, Salsabil Darma Ma'arif3, Imelda Ayu Shinta Riansyah ${ }^{3}$, Maylian Giofany4, \\ Ika Nur Rokhmawati ${ }^{3}$, Rinaldo Agestwo ${ }^{5}$, Alan Duana Putra ${ }^{5}$, Ach Sahroni ${ }^{5}$ \\ ${ }^{1}$ Fakultas Ilmu Administrasi, Universitas Islam Malang \\ ${ }^{2}$ Fakultas Kedokteran, Universitas Islam Malang \\ ${ }^{3}$ Fakultas Agama Islam, Universitas Islam Malang \\ ${ }^{4}$ Fakultas Keguruan dan Ilmu Pendidikan, Universitas Islam Malang \\ ${ }^{5}$ Fakultas Teknik, Universitas Islam Malang
}

Korespondensi email: sekarsari@unisma.ac.id

\begin{abstract}
ABSTRAK
Desa adalah wilayah yang berpengaruh penting dalam perekonomian. Desa adalah wilayah penyangga yang menyediakan lumbung pangan di seluruh Indonesia. Ketahanan pangan tidak terlepas dari peran desa dalam melestarikan budaya agraris di Indonesia. Di era globalisasi seperti saat ini akses informasi sangat mudah dan dengan pembangunan infrastruktur jalan yang semakin gencar wilayah desa semakin maju. Pembangunan infrastruktur jalan itu bukan hanya semata untuk menunjang operasional pemerintah dalam mengelola ekonomi tetapi juga untuk eksplorasi pengembangan potensi yang ada di desa. Desa wisata saat ini telah menjadi alternatif dalam pembangunan ekonomi lokal yang telah diterapkan di berbagai daerah. Berwisata di desa, kini telah menjadi pilihan tersendiri bagi wisatawan. Wisatawan menggemari tempat wisata di desa tidak hanya menyajikan keindahan alamnya saja tetapi juga dapat berinteraksi dengan masyarakat lokal. Oleh karena itu, berkembanglah alternatif pariwisata pada minat khusus dan lokasi tertentu yang disebut dengan desa wisata dalam menggali dan meningkatkan potensi desa adalah Desa Wonoayu. Metode penelitian yang digunakan dalam penelitian ini menggunakan pendekatan deskriptif kualitatif yang dilaksanakan di Desa Wonoayu, Kecamatan Wajak, Kabupaten Malang. Teknik pengumpulan data menggunakan observasi, wawancara, dan dokumentasi dengan subjek penelitian. Hasil penelitian yang telah bekerjasama dengan masyarakat sekitar untuk menata ulang dan menggali obyek-obyek wisata yang belum ada sehingga dapat dikunjungi wisatawan nusantara maupun wisatawan mancanegara.
\end{abstract}

Kata Kunci: potensi desa; desa wisata; ekonomi lokal.

\section{PENDAHULUAN}

Indonesia merupakan negara yang memiliki banyak potensi dalam aspek pariwisata. Dalam pengembangannya, pariwisata melibatkan sektor-sektor lain seperti pertanian, perhubungan, perdagangan dan jasa, industri serta sektor lainnya. Sehingga dalam pengembangan sektor pariwisata akan memberikan pengaruh pada pengembangan sektorsektor lain (Ariyani et al., 2015).

Pengembangan sektor pariwisata merupakan upaya yang dapat meningkatkan pendapatan dan pembangunan asli daerah. Namun sektor pariwisata masih memiliki beberapa kendala sehingga diperlukan strategi yang tepat untuk mengembangkan 
pariwisata oleh beberapa elemen masyarakat. Salah satu pendekatan untuk merealisasikan pembangunan pariwisata adalah dengan mengemas suatu pedesaan menjadi desa wisata (Nurhadi et al., 2014) (Ayu, 2019). Pengembangan desa wisata merupakan upaya untuk mengembangkan serta memperkenalkan potensi-potensi yang ada di wilayah tersebut. Sehingga dapat dijadikan wisata bagi penduduk lokal maupun luar desa yang sekaligus dapat memberikan manfaat bagi desa tersebut (Rabiatul Adawiyah et al., 2017) (Putri et al., 2018).

Desa Wonoayu merupakan salah satu desa yang terletak di Kecamatan Wajak Kabupaten Malang. Desa yang terletak di ketinggian $630 \mathrm{Mdpl}$ ini memiliki berbagai daya tarik berupa kekayaan alam dan tanah yang subur. Hal ini menjadikan sebagian besar perekonomian rakyat di desa ditopang oleh sektor pertanian dan peternakan. Selain itu, terdapat pula beberapa daya tarik lain yang dimiliki misalnya lapangan sepakbola, lapangan voli dan greenhouse yang letaknya berdekatan.

Daya tarik di Desa Wonoayu mempunyai potensi wisata yang cukup besar yang dapat dikembangkan. Saat ini, lapangan sepakbola memiliki peran sentral dalam menarik wisatawan dari dalam maupun luar Desa Wonoayu, yang seringkali dimanfaatkan untuk pengadaan acara besar dan tempat olahraga warga bahkan tim sepakbola besar seperti AREMA FC. Atas dasar ini, peningkatan potensi wisata dapat dikembangkan dengan penambahan daya tarik di sekitar lapangan bola, salah satunya greenhouse. Greenhouse yang sudah ada dilakukan upaya revitalisasi dan dikemas lebih menarik agar meningkatkan minat wisatawan untuk berkunjung.

Greenhouse yang telah berfungsi sebagai tempat pembibitan dikembangkan sebagai sarana pembelajaran dan rekreasi (Nasihien et al., 2017) (Fitriawan et al., 2018). oleh karena itu, munculah inovasi untuk mengembangkan edukasi wisata yang berbasis pertanian dengan menjadikan pengelola lahan demplot sebagai narasumber dalam hal eduwisata. Hal ini bertujuan untuk memberikan informasi dan sekaligus pengetahuan kepada pengunjung greenhouse Desa Wonoayu agar sadar akan potensi di lingkungan sekitar. Greenhouse tersebut akan dipasarkan dengan melakukan promosi melalui media sosial dan media lainnya.

Dalam membangun sebuah desa menjadi Desa Wisata, maka pertama yang harus dilihat adalah kondisi yang terdapat di Desa tersebut. Selain itu, sebuah desa membutuhkan perencanaan dalam mengembangkan desa tersebut menjadi Desa Wisata dalam jangka panjang (Ayu, 2019). Kondisi yang terjadi di Desa Wonoayu.

Desa Wonoayu masih minim dengan jumlah kunjungan wisata. Potensi unggulan yang dimiliki Desa Wonoayu yaitu adanya obyek wisata alam, lapangan dan greenhouse serta sentra industri rumah tangga berupa UMKM kripik nangka. Rendahnya jumlah kunjungan wisatawan ke Desa Wonoayu akibat dari:

1. Tidak adanya perencanaan pengembangan desa wisata jangka pendek/panjang.

2. Promosi/pemasaran desa wisata kurang optimal.

3. Tidak adanya penataan kawasan desa wisata.

4. Tata kelola kelembagaan, manajemen desa wisata yang tidak baik.

5. Tidak adanya pengemasan potensi wisata yang menarik.

Berdasarkan dari identifikasi permasalahan tersebut di atas, permasalahan tersebut akibat dari:

1. Rendahnya SDM masyarakat dalam pengembangan Desa Wisata.

2. Promosi Desa Wisata kurang optimal.

Oleh karena itu, sebagai bentuk aplikasi keilmuan mahasiswa terhadap masyarakat, untuk mengoptimalkan pengembangan obyek wisata Desa Wonoayu, telah ditempuh 
penggagasan ide MASDARWIS ALIM (Masyarakat Sadar Wisata Alam dan Ilmu Pengetahuan) yang disetujui perangkat desa dengan menawarkan gagasan berupa:

1. Peningkatan potensi pariwisata berbasis Wisata Desa dengan melakukan pembenahan dan penambahan fasilitas atau yang lainnya.

2. Promosi desa melalui media sosial atau website yang menarik.

3. Pengadaan paket wisata sesuai potensi yang ada di wilayah tersebut yang berbasis Field Trip.

Dalam pelaksanaan program yang akan ditawarkan tersebut, ada beberapa kendala yang dapat menghambat proses berjalannya kegiatan tersebut, antara lain:

1. Persediaan air yang terbatas dan jauh

Secara umum, Desa Wonoayu memiliki masalah keterbatasan air selama pelaksanaan KKN ini. Selain itu di tempat pembibitan, pompa air terdekat untuk penyiraman harian dirasa cukup jauh, sehingga mengurangi efektivitas dalam perawatan tanaman dan taman secara umum.

2. Jenis tanaman yang kurang bervariatif

Di Desa Wonoayu terdapat berbagai tanaman yang kurang bervariatif seperti daun bawang dan terong yang ditanam di greenhouse. Selain itu banyak sekali jagung yang ditanam disekitar lingkungan Desa Wonoayu.

Pariwisata merupakan fenomena yang muncul karena adanya interaksi antara wisatawan, penyedia jasa/industri wisata, dan pemerintah dalam menyediakan fasilitas dan layanan yang mendukung kegiatan wisata (Suwena \& Widyatmaja, 2017). Menurut Tyas \& Damayanti (2018), sistem pariwisata terjadi akibat kesesuaian antara komponen sediaan (supply) dan permintaan (demand). Komponen sediaan yang dimaksud meliputi daya tarik, akomodasi, transportasi, pelayanan, informasi dan promosi. Sedangkan komponen permintaan adalah segala hal yang berhubungan dengan permintaan pariwisata yang berasal dari wisatawan.

Komponen permintaan bertindak sebagai pasar (market), yakni menentukan apa yang diinginkan oleh wisatawan, kebutuhan dan kemampuan wisatawan dalam membayar. Meski sistem pariwisata digambarkan melalui sistem yang tertutup (closed system), namun model ini dapat digunakan untuk menganalisis komponen penting dalam penyediaan daya tarik pada suatu destinasi wisata (Fajriasanti, 2010).

Terdapat sembilan faktor eksternal dalam sistem pariwisata, di antaranya: (a) sumberdaya alam; (b) kebudayaan; (c) kewirausahaan; (d) keuangan dan pembiayaan; (e) tenaga kerja; (f) kompetisi; (g) masyarakat; (h) kebijakan pemerintah; (i) organisasi/ kelembagaan.

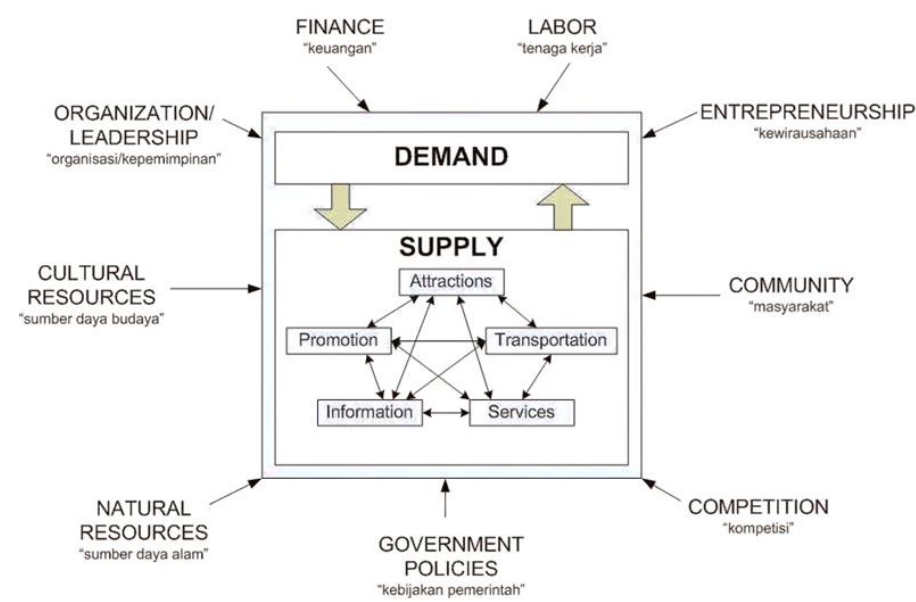

Gambar 1. Sistem pariwisata dan faktor eksternal dalam sistem pariwisata. 


\section{Pengembangan Sarana dan Prasarana Pariwisata}

Menurut Muktaf \& Zulfiana (2018) wisatawan adalah orang yang melakukan perjalanan sementara waktu ke tempat atau daerah yang sama sekali masih asing baginya. Oleh karena itu sebelum seorang wisatawa melakukan perjalanan wisatanya, terlebih dahulu kita menyediakan prasarana dan sarana pariwisata seperti berikut:
a. Fasilitas transportasi,
b. Fasilitas akomodasi,
c. Fasilitas Catering Service,
d. Obyek dan atraksi wisata,
e. Aktivitas rekreasi,
f. Fasilitas pembelanjaan,
g. Tempat atau toko.

Semua ini merupakan prasarana dan sarana kepariwisataan yang harus diadakan sebelum kita mempromosikan suatu daerah tujuan wisata. Sedangkan mengenai prasarana (infrastruktur) adalah semua fasilitas yang dapat memungkinkan proses perekonomian berjalan dengan lancar sedemikan rupa. Dalam melaksanakan fungsi dan peranannya dalam pengembangan pariwisata di daerah, pemerintah daerah harus melakukan berbagai upaya dalam pengembangan sarana dan prasarana pariwisata. Sarana pariwisata terbagi menjadi tiga bagian penting, yaitu:
a. Sarana Pokok Pariwisata (Main Tourism Superstructures) adalah: Hotel, Villa, Restoran.
b. Sarana Pelengkap Pariwisata (Suplementing Tourism Superstructures) adalah: wisata budaya dan wisata alam.
c. Sarana Penunjang Pariwisata (Supporting Tourism Superstructures) seperti pasar seni, kuliner, oleh-oleh dan cindera mata kerajinan khas daerah.

\section{Pengembangan Pariwisata}

Menurut Nurhadi et al. (2014), pengembangan pariwisata memiliki tiga fungsi yaitu: (1) menggalakkan ekonomi, (2) memelihara kepribadian bangsa\&kelestarian fungsi dan mutu lingkungan hidup, (3) memupuk rasa cinta tanah air dan bangsa. Silitonga \& Anom (2016) menyebutkan bahwa potensi wisata adalah segala sesuatu yang dapat dikembangkan menjadi daya tarik wisata. Potensi wisata dapat di bagi menjadi dua (2) yaitu potensi budaya dan potensi alamiah.

a. Potensi Budaya, Potensi yang dimaksudkan adalah adanya wisata budaya yang masih kental dengan adat istiadat yang dimiliki oleh Desa Wonoayu.

b. Potensi Alamiah, potensi yang dimaksudkan meliputi Obyek wisata yang berpotensi besar dapat dikembangkan

\section{METODE}

Pengabdian ini bertempat di Pemerintah Desa dan Masyarakat Desa Wonoayu Kecamatan Wajak dilaksanakan dalam kurun waktu satu bulan selama kegiatan KKN PPM Tematik berlangsung. Teknik pengumpulan data pada kegiatan ini menggunakan observasi, wawancara, dan dokumentasi. Dalam melaksanakan kegiatan ini sangat dibutuhkan partisipasi dari pemerintah desa selaku tuan rumah, dan masyarakat sebagai peserta supaya program dapat berjalan dan berkelanjutan dengan program kegiatan sosialisasi mengenai proker yang akan dilakukan dengan pihak Pemerintah Desa dan pihak wanita tani desa untuk mencari mitra untuk pembenahan fasilitas. Kemudian dilanjutkan pembenahan fasilitas, promosi dan terakhir finishing. 


\section{HASIL DAN PEMBAHASAN}

Pengelolaan desa wisata yang berbasis lokal memerlukan kepedulian dan partisipasi masyarakat sendiri untuk senantiasa berinovasi dan kreatif dalam mengembangan wilayah desanya yang dijadikan sebagai desa wisata. Menurut Cohen dan Uphoff (1979) peran atau partisipasi yang dilakukan oleh masyarakat bias dilihat mulai dari tahap perencanaan, pelaksanaan, pengelolaan atau pemanfaatan, pengawasan, menikmati hasil dan evaluasi. Pengembangan desa wisata ini harus memerhatikan kemampuan dan tingkat penerimaan masyarakat setempat yang akan dikembangkan menjadi desa wisata.

Pelaksanaan KKN-PPM tematik ini melalui beberapa tahapan yaitu tahap persiapan, tahap pelaksanaan serta tahap pelaporan. Pada tahap pelaksanaan, dilakukan kegiatan sesuai perancanaan awal selama 4 minggu meliputi tahap sosialisasi pada pekan pertama, dilanjutkan tahap pembenahan fasilitas, serta tahap maintenance dan finishing berturutturut pada pekan kedua hingga keempat.

\section{Tahap Sosialisasi.}

Kegiatan awal yang dilakukan di Desa Wonoayu Kecamatan Wajak adalah sosialisasi dengan kelompok Wanita Tani Desa dan ibu-ibu PKK. Sebelum diadakan sosialisasi dengan para Wanita Tani Desa dan PKK, kami menemui para pihak Pemerintah Desa dan berbicara mengenai kegiatan yang akan dilakukan selama 1 bulan di Desa Wonoayu serta rencana kami melaksanakan kegiatan Sosialisasi yang akan dilaksanakan di Balai Desa pada tanggal 5 Februari 2020. Kegiatan sosialisasi dilaksanakan untuk mencari mitra dalam penambahan bibit pembenahan fasilitas di greenhouse.

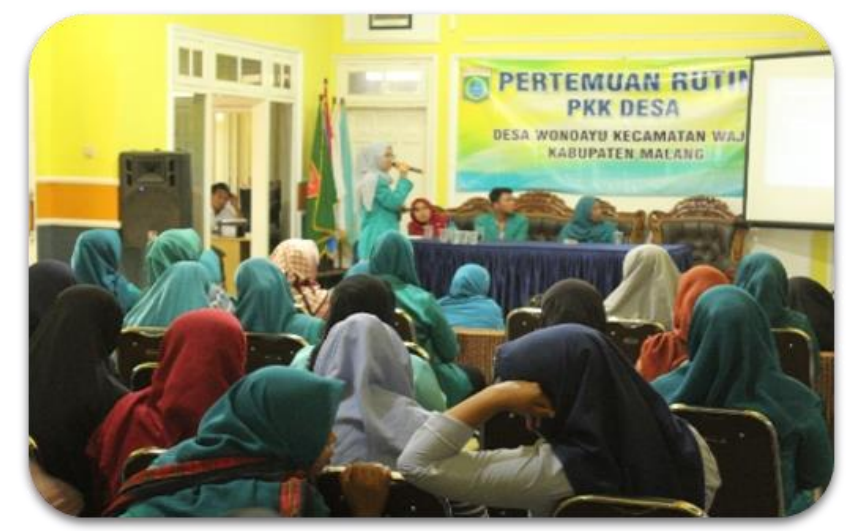

Gambar 2. Kegiatan sosialisasi dengan kelompok Wanita Tani Desa dan ibu-ibu PKK

\section{Tahap Pembenahan dan Penambahan Fasilitas.}

Renovasi papan nama Desa Wonoayu di depan greenhouse sebagai bagian dari program pembenahan fasilitas di Desa Wonoayu tersebut. Pembenahan papan nama Desa Wonoayu dilakukan dengan bantuan penguruus lapangan dan bapak-bapak desa yang diawali dengan penurunan genteng papan nama Desa Wonoayu, pencabutan papan nama dan terakhir penananaman bunga hias di depan papan nama Desa Wonoayu. 


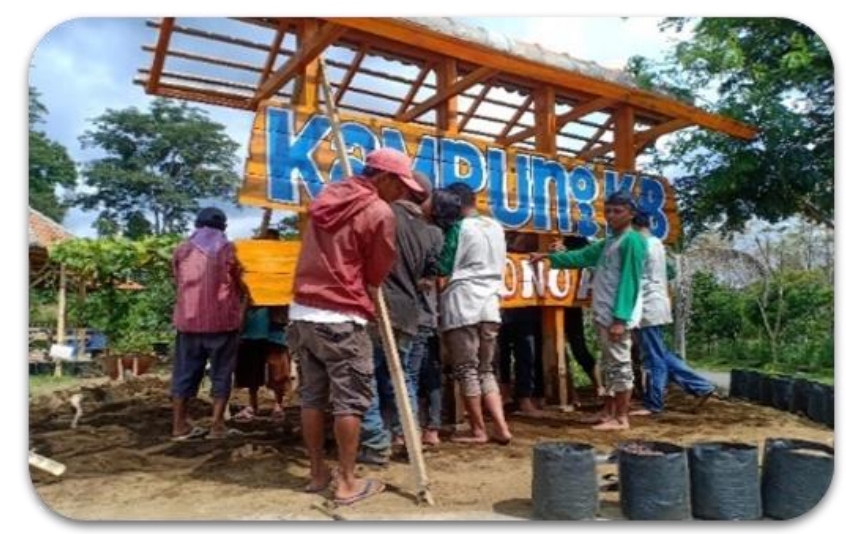

Gambar 3. Merenovasi papan nama Desa Wonoayu

Dalam tahap ini, kegiatan yang akan dilakukan adalah pembersihan lahan, pendatangan bibit dan penanaman, penataan lahan dan terakhir dilanjutkan dengan pembuatan vertikal garden.

Kegiatan selanjutnya adalah penanaman bibit stroberi dalam polybag yang dibantu dengan para Wanita Tani Desa dan ibu-ibu PKK. Penanaman bibit stroberi dilakukan sebagai bagian dari program kerja yaitu penambahan bibit di greenhouse dan lahan demplot serta sebagai pengganti tanaman yang tidak terawat dalam jumlah 100 bibit.

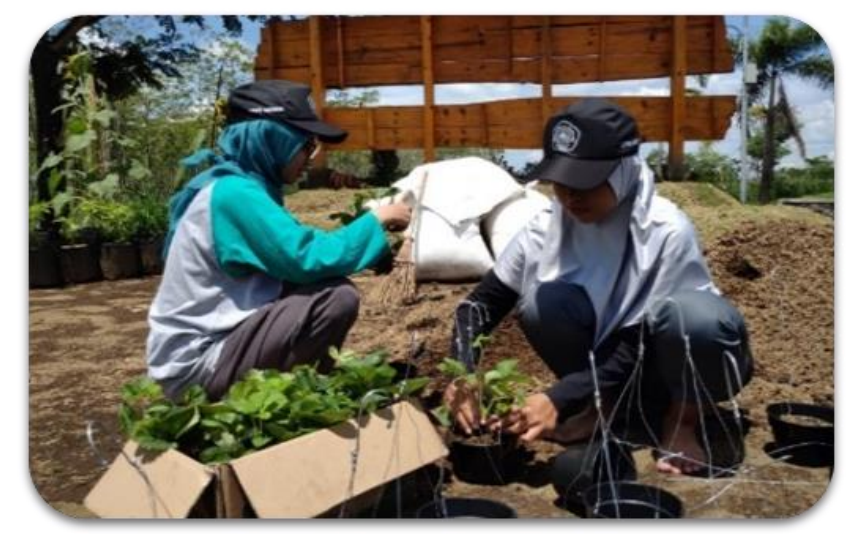

Gambar 4. penanaman bibit stroberi dalam polybag

Selain penambahan bibit stroberi, juga penanaman bunga krokot di dalam botol bekas berukuran $1500 \mathrm{~mL}$ yang sebelumnya sudah dicat terlebih dahulu dan diberi gantungan kawat.

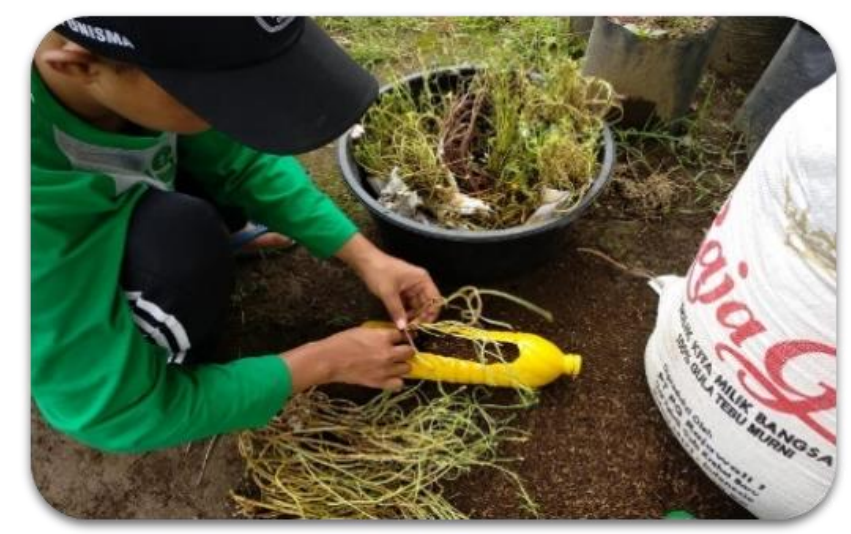

Gambar 5. penanaman bunga krokot di dalam botol bekas 


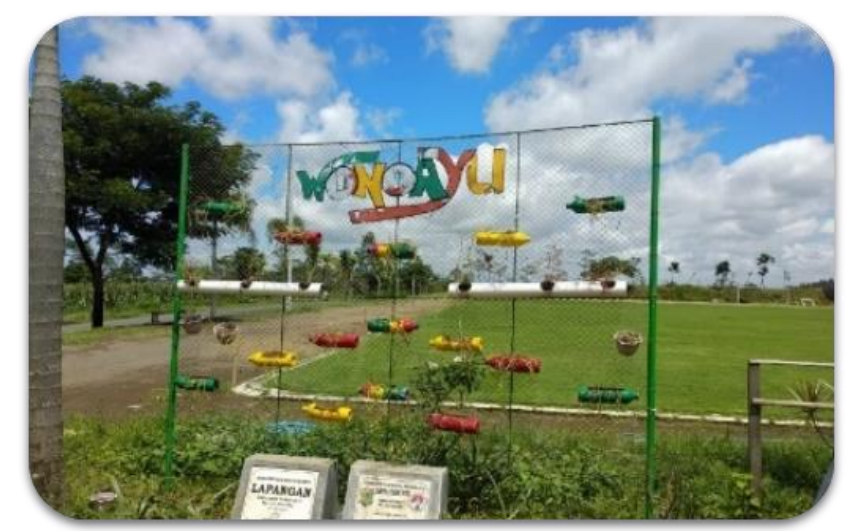

Gambar 6. Penambahan fasilitas spot foto

\section{Tahap Promosi dan Finishing.}

Promosi dilakukan melalui media foto dan video serta website yang menarik. Kemudian dilanjutkan pada tahap finishing di akhir kegiatan KKN.

\section{KESIMPULAN}

Pelaksanaan program kerja KKN PPM Tematik dalam pengembangan Desa Wisata di Desa Wonoayu Kecamatan Wajak melalui pembenahan dan penambahan fasilitas seperti renovasi papan nama Desa Wonoayu, penambahan bibit stroberi dalam polybag dan bunga krokot dalam botol bekas mendapat respon yang positif dari Kepala Desa Wonoayu dan masyarakat Desa Wonoayu Kecamatan Wajak. Hasil yang dicapai dalam pelaksanaan program kerja KKN-PPM Tematik ini diantaranya adalah peningkatan potensi pariwisata, ekonomi, dan peningkatan pengetahuan SDM dalam sadar wisata serta pemasarannya melalui media online. Pengembangan Desa Wisata Wonoayu ini dapat mewujudkan kepuasan para wisatawan yang berkunjung ke Desa Wonoayu.

Diharapkan masyarakat Desa Wonoayu Kecamatan Wajak dapat melanjutkan program-program yang telah dirintis mahasiswa KKN UNISMA. Dukungan warga masyarakat terutama Wanita Tani Desa dan Ibu-Ibu PKK serta remaja sangat kami harapkan untuk melaksanakan dan melanjutkan program/kegiatan tersebut dalam mewujudkan Desa Wisata Wonoayu

\section{DAFTAR RUJUKAN}

Ariyani, N., Demartoto, A., \& Zuber, A. (2015). Habitus Pengembangan Desa Wisata Kuwu: Studi Kasus Desa Wisata Kuwu Kecamatan Kradenan Kabupaten Grobogan. Jurnal Analisa Sosiologi, 4(2), 227591. https://doi.org/10.20961/jas.v4i2.17436

Ayu, I. K. (2019). Mengembangkan Potensi Desa Bringin Menjadi Desa Wisata. Jurnal Pembelajaran Pemberdayaan Masyarakat (JP2M), 1(1), 1-5. https://doi.org/10.33474/jp2m.v1i1.4992

Fitriawan, H., Dwipakresna, M., Sulistyanti, S. R., \& Trisanto, A. (2018). Pemantauan dan Pengendalian Kondisi Lingkungan Greenhouse Tanaman Paprika dengan Teknologi ZigBee. Seminar Nasional Teknik Elektro 2018, 185-188.

Muktaf, Z. M., \& Zulfiana, E. R. (2018). Persepsi Wisatawan Asing Terhadap Wisata Indonesia. Cakrawala: Jurnal Penelitian Sosial, 7(1), 83-106. https://ejournal.uksw.edu/cakrawala/article/view/1781

Nasihien, R. D., Wulandari, D. A. R., Zacoeb, A., . H., \& Setiawan, M. I. (2017). Teknologi Portable Inflated Greenhouse Sebagai Fasilitas Pendukung Peningkatan Ketahanan Pangan Dan Pertanian Perkotaan (Urban Farming). Jurnal Darussalam: Jurnal 
Pendidikan, Komunikasi Dan Pemikiran Hukum Islam, 9(1), 161-183. https://doi.org/10.30739/darussalam.v9i1.123

Nurhadi, F. D. C., Mardiyono, \& Rengu, S. P. (2014). Strategi Pengembangan Pariwisata Oleh Pemerintah Daerah Terhadap Pendapatan Asli Daerah (PAD) (Studi Pada Dinas Pemuda, Olahraga, Kebudayaan Dan Pariwisata Kabupaten Mojokerto). Jurnal Administrasi Publik Mahasiswa Universitas Brawijaya, 2(2), 325-331. http://administrasipublik.studentjournal.ub.ac.id/index.php/jap/article/view/374

Putri, R. A. S. I., Sinyor, E. P., \& Putri, A. C. (2018). Strategi Pengembangan Potensi Desa Wisata Berbasis Analisis Swot Desa Sidomekar Dan Penggunaan Aplikasi Tour Guide Online Kabupaten Jember. Seminar Nasional Manajemen Dan Bisnis Ke-3, 173-187.

Rabiatul Adawiyah, W., Praptapa, A., \& Mafudi. (2017). Strategi Pengembangan Desa Wisata Berbasis Masyarakat (Community Based Rural Tourism) Di Desa Papringan. Prosiding Seminar Nasional Dan Call for Paper, 5(November), 1072-1083.

Silitonga, S. S. M., \& Anom, I. P. (2016). Kota Tua Barus Sebagai Daerah Tujuan Wisata Sejarah Di Kabupaten Tapanuli Tengah. Jurnal Destinasi Pariwisata, 4(2), 7-13. https://doi.org/10.24843/despar.2016.v04.i02.p02

Suwena, I. K., \& Widyatmaja, I. G. N. (2017). Pengatahuan Ilmu Dasar Pariwisata (Edisi Revi, p. 240). Pustaka Larasan.

Tyas, N. W., \& Damayanti, M. (2018). Potensi Pengembangan Desa Kliwonan sebagai Desa Wisata Batik di Kabupaten Sragen. Journal of Regional and Rural Development Planning, 2(1), 74-89. https://doi.org/10.29244/jp2wd.2018.2.1.74-89 